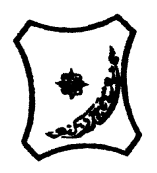

Bayero Journal of Pure and Applied Sciences, 10(1): 223 - 226

Received: June, 2015

Accepted: November, 2016

ISSN $2006-6996$

\title{
THE EFFECTS OF TEMPERATURE AND RELATIVE HUMIDITY ON THE GROWTH OF THREE ISOLATED FUNGI FROM RICE (Oryza sativa L.) SEEDLINGS IN DADIN KOWA IRRIGATION SCHEME, DADINKOWA, GOMBE
}

\author{
Modibbo, U. D ${ }^{1 *}{ }_{\text {, }}$ Chimbekujwo, I. B ${ }^{2}$,, Pola, B. B ${ }^{2}$, Channya, F. K, ${ }^{2}$ Hayatuddeen, A.M. ${ }^{1}$ \\ and Abdullahi, $\mathbf{G}^{\mathbf{1}}$. \\ ${ }^{1}$ Department of Agricultural Education Federal College of Education (Tech) Gombe, Gombe State \\ ${ }^{2}$ Department of Plant Sciences Modibbo Adama University of Technology, Yola, Adamawa State \\ * e-mail address: dangiwafaruk@gmail.com
}

\section{ABSTRACT}

The effects of temperature and relative humidity on the growth of three isolated fungi (Aspergillus parasiticus, Altenaria alternata and Thielavia terricola) associated with rice seedlings rot in Dadin Kowa Irrigation Scheme, Gombe, Nigeria were investigated. Temperature in the ranges of $10^{\circ} \mathrm{C}$, $15^{\circ} \mathrm{C}, 25^{\circ} \mathrm{C}, 30^{\circ} \mathrm{C}, 35^{\circ} \mathrm{C}$ and $40^{\circ} \mathrm{Cwere}$ used to determine the temperature effect on the growth of these fungi. These fungi were also cultured on 100, 91, 80, 59.5, 47 and $32.5 \%$ relative humidity. Highest growth of these fungi was obtained at $25^{\circ} \mathrm{C}$ and $30^{\circ} \mathrm{C}$ temperatures. The fungi showed highest growth at 80 and $91 \%$ relative humidity. The growth of these fungi was observed to increase with increase in relative humidity and vice versa. Statistical application for Sciences (SAS) was used to analyze the data generated and the least significant difference, was used to separate the means. There were significant differences $(P \leq 0.05)$ in the growth of these fungi at different temperature and relative humidity regimes.

Keywords: Temperature, Relative Humidity, Growth, Rice, Fungi, Dadin Kowa

\section{INTRODUCTION}

Rice (Oryza sativa L.) is a monocotyledonous cereal crop which belongs to the grass family Poacea (formerly graminae). In Nigeria rice (grown on 1.77 million ha) ranks sixth after sorghum (4.0 million ha), millet (3.5 million ha), cassava (2.0 million ha) and yam (2.0 million ha), but if placed on a social scale, it can as well be ranked first because it is no longer just a mere festival meal, but the staple of most homes in urban and rural areas (Ekeleme et al., 2008)

Several studies were conducted on the effect of environmental factors on the growth of fungal pathogens (Malik and Singh 2004; Kim and Xiao, 2005). Environmental factors such as relative humidity and temperature were reported to have a significant influence on the growth and development hence virulence, of a variety of fungi. Growth rate of fungi varies depending on temperature and relative humidity. The optimum growth temperatures for the majority of fungi studied was found to fall between $25^{\circ} \mathrm{C}$ and $30^{\circ} \mathrm{C}$ and above $40^{\circ} \mathrm{C}$ the growth was poor and in some cases mortality may occur (Sharma and Razak, 2003).Bristone et al. (2011) reported that temperature ranges of $10-25^{\circ} \mathrm{C}$ inhibited the growth of Penicillium expansum and Rhizopus stolonifer. Channya (1991) also found that the presence of moisture (Relative Humidity) predisposed plant tissues to microbial infection, moisture, were required for spore germination on the host surface and also protects the germ tubes from desiccation before invading the host tissues. He also detected that temperature range of $35-40^{\circ} \mathrm{C}$ affected the growth of many fungi as regards their ability to cause rotting. Chimbekujwo (1994) also reported that potato rot was fast between temperature range of $25-30^{\circ} \mathrm{C}$ and relative humidity range of $32.5-100 \%$. Reis et al. (2006) on the study of effect of lesion age, humidity and fungicide application on sporulation of Alternaria alternata, the cause of brown spot of Tangerine, reported that the number of conidia produced was low at $74 \%$ relative humidity and greater at $80 \%$ relative humidity. The percentage relative humidity of lesion producing conidia was very low at $74 \%$, increased at higher relative humidity of $80-85 \%$ and declined slightly at $100 \%$.

However, little information is available on the influence of environmental factors on the growth of the fungi, Aspergillus parasiticus, Altenaria alternata and Thielavia terricola. Therefore, the main objective of the study was to investigate the effect of temperature and relative humidity on the growth of these fungi. This may contribute in reducing heavy losses incurred annually by rice farmers at the irrigation schemes as a result of the devastating effect of these fungi on rice seedlings both at harvest and post-harvest levels.

\section{MATERIALS AND METHODS}

\section{Samples Collection and Processing}

Diseased rice seedlings were collected from rice farms in the Dadin kowa irrigation scheme and transported to the Biological Science Department, Gombe State University. The diseased samples were surface sterilized and cut into pieces of root portion, stem portion and head portion separately using sterilized hand knife. The pieces were transferred onto Petri dishes containing potato dextrose agar media using sterile spatula which was sterilized using Bunsen flame and dipped it into methylated spirit. 


\section{Bajopas Volume 10 Number 1 June, 2017}

\section{Isolation and Identification of the Fungi}

A portion of the diseased rice plant was cut into smaller pieces with sterile hand knife on a sterile wooden surface and the pieces were transferred into sterile Petri-dishes with a sterile spatula which was flamed over a Bunsen flame and dipped inside methylated spirit (Thomas, 1979). The cut piece were surface-sterilized with $0.01 \%$ mercuric chloride for 30 seconds, rinsed in five changes of sterile distilled water, and was blotted dry with sterile Whatman No. 1 filter papers. Cut pieces were plated aseptically on 9 $\mathrm{cm}$ Petri dishes containing solidified PDA to which 0.3 $\mathrm{g}$ tetracycline was added to inhibit the growth of bacteria. Solidified plates were incubated at room temperatures $\left(28-32^{\circ} \mathrm{C}\right)$ for 4 days. Fungal colonies growing from the incubated plates were sub-cultured into fresh PDA media until pure cultures were obtained. Microscopic examinations were carried out after examining the colony characteristics. A sterile needle was used in taking a little portion of the hyphae, containing spores onto sterile glass slide stained in lacto phenol cotton blue and examined under the microscope for the fungal structures (Frazier, 1978). The morphological, and cultural characteristics observed under the microscope was compared with structures in Alexopoulus and Mims (1986), as well as Snowdon (1990).

\section{Effect of Relative Humidity on the Growth of the Fungi}

Six different relative humidity regimes were obtained as proposed by Winston and Bates (1960). Such relative humidity was obtained by dissolving each salt at $30^{\circ} \mathrm{C}$ until the saturation state was reached. The six different relative humidity regimes $32.5 \%, 47 \%$, $59.5 \%, 80 \%, 91 \%$, and $100 \%$ were obtained using desiccators by dissolving the following salts: Magnesium chloride $\left(\mathrm{MgCl}_{2}\right)$, calcium nitrate $\left(\mathrm{Ca}\left(\mathrm{NO}_{3}\right)_{2}\right)$, ammonium nitrate $\left(\mathrm{NH}_{4} \mathrm{NO}_{3}\right)$, ammonium sulphate $\left(\mathrm{NH}_{4} \mathrm{SO}_{4}\right)$ and potassium nitrite $\left(\mathrm{KNO}_{2}\right)$ above their saturated solutions, and distilled water respectively. Kim and Xiao (2005) method was adopted whereby $(2 \mathrm{~mm})$ of 3 days pure culture of the isolated fungi were inoculated on a sterile Petri dish containing PDA medium and arranged in the upper chamber of the desiccators containing the desired salts and allowed to stand for 4 hours to attain the relative humidity required. A plate containing the isolated organisms was incubated in desiccators containing each relative humidity regime. This was allowed for 24 hours after which the progress of radial growth was measured for four consecutive days. The experiment was replicated four times.
Effects of Temperature on the Growth of Fungi

Six temperature regimes used for this study were 10 , $15,25,30,35$ and $40^{\circ} \mathrm{C}$. The variations of temperature were obtained by setting the incubators to the required temperatures. A $2 \mathrm{~mm}$ diameter of the youngest of 3-day old colony of the fungus was inoculated into a solidified (PDA media) and transferred into the incubator which was initially set at the required temperature regimes for four days. The experiment was replicated four times for each of the temperature regimes.

\section{RESULTS AND DISCUSSION}

The results of the growth of the isolated fungi (Aspergillus parasiticus, Altenaria alternata and Thielavia terricola) are presented in Table 1.The temperature regimes tested supported the growth of the fungi. However,the results of the growth of the three species of fungi isolated at varying regimes of $10^{\circ} \mathrm{C}, 15^{\circ} \mathrm{C}, 25^{\circ} \mathrm{C}, 30^{\circ} \mathrm{C}, 35^{\circ} \mathrm{C}, 40^{\circ} \mathrm{C}$ showed an increase in radial growth mean value from $10^{\circ} \mathrm{C}$ being the lowest growth temperature to $35^{\circ} \mathrm{C}$ as the optimum temperature for the growth of the organisms. Aspergillus parasiticus and A/ternaria alternate temperature has a highly significant effect on their growth and development as shown by their $\mathrm{P}$ -values (0.0012 and 0.002) compared to $\mathrm{P} \leq 0.05$.Thus, the lower the $\mathrm{P}$-value for a given isolated organism over the temperature regime it was subjected the higher the significant the temperature regime will be for their growth and development. However, their respective radial growth mean values stood at $2.03 \mathrm{~mm}$ and $2.07 \mathrm{~mm}$ respectively. Statistical analysis showed a highly significant effect of temperature on the isolated fungi $(P \leq 0.05)$ at $10^{\circ} \mathrm{C}, 15^{\circ} \mathrm{C}$ and $40^{\circ} \mathrm{C}$. Temperature also had a significant effect on the growth and development of Thielavia terricola as shown by its P-value (0.0224) and its radial growth mean value stood at $2.04 \mathrm{~mm}$.

The results of the three species of the isolated fungi at varying relative humidity regimes of $32.5 \%, 47 \%$, $59.5 \%, 80 \%, 91 \%$ and $100 \%$; showed that the effect of relative humidity on Alternaria altenata was highly significant as its $P$ - value $(0.02)$ a value below the set $P$ - value $(0.05)$. Therefore the lower the $P$ value the higher the significant is the effect of the relative humidity on the isolated fungi, also the radial growth mean value stands at $2.03 \mathrm{~mm}$. On the other hand Aspergillus parasiticus was significantly affected by the relative humidity as shown by its $P$ - value (0.06) and its radial growth mean value was 2.38 $\mathrm{mm}$. At the relative humidity of $32.5 \%$ to $100 \%$ the radial growth mean value of the Aspergillus parasiticus performed well. While Thielavia terricola responded to some relative humidity regimes of 47 $\%, 59.5 \%$ and $91 \%$ and failed at $32.5 \%, 80 \%$ and $100 \%$. 
Bajopas Volume 10 Number 1 June, 2017

Table 1: Effect of Different Temperature Regimes on the Radial Growth in Millimeter ( $\mathrm{mm}$ ) of the Isolated Fungi

\begin{tabular}{cccc}
\hline $\begin{array}{c}\text { Temp. } \\
\left({ }^{0} \mathrm{C}\right)\end{array}$ & $\begin{array}{c}\text { Altenaria } \\
\text { altanata }\end{array}$ & $\begin{array}{c}\text { Aspergillus } \\
\text { parasiticus }\end{array}$ & $\begin{array}{c}\text { Thielavia } \\
\text { terricola }\end{array}$ \\
\hline 10 & 2.00 & 2.10 & 2.00 \\
15 & 2.00 & 2.10 & 2.10 \\
25 & 2.05 & 2.00 & 2.05 \\
30 & 2.00 & 2.08 & 2.10 \\
35 & 2.03 & 2.13 & 2.00 \\
40 & 2.10 & 2.00 & 2.00 \\
Mean & 2.03 & 2.07 & 2.04 \\
LSD & 0.05 & 0.07 & 0.08 \\
P-Value & $0.0012 * *$ & $0.002 * *$ & $0.0224 *$ \\
\hline
\end{tabular}

Values represent means of quadruplicate Petri dish

Key:

** $=$ Highly significant at $(P \leq 0.05), *=$ Significant at $(P \leq 0.05)$

Table 2: Effect of Different Relative Humidity on the Radial Growth in Millimeter (mm) of Isolated Fungi

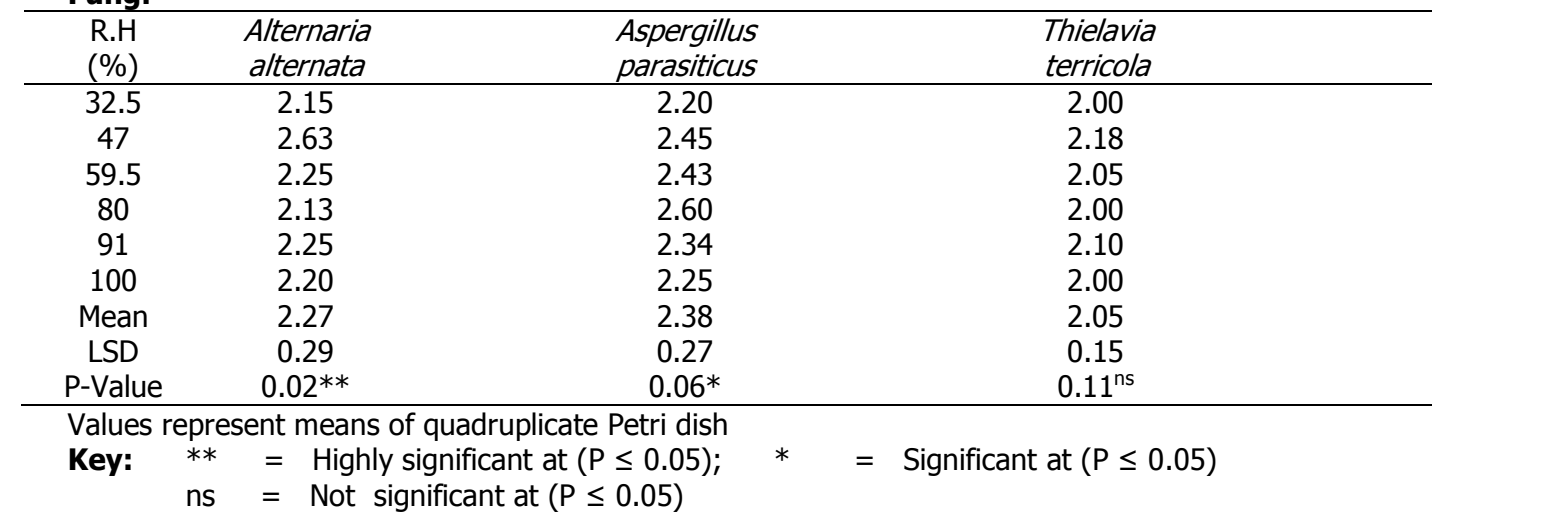

In this research, the three (3) isolated fungi responded differently to the temperature ranges, their growth rate on the rice seedlings showed that the optimum growth temperature for Alternaria alternata, Aspergillus parasiticus and Thielavia terricola were between the ranges of $10^{\circ} \mathrm{C}$ to $35^{\circ} \mathrm{C}$. This supports the report by Chimbekujwo (1994) in his studies of pawpaw rot. However, a lower temperature of $10^{\circ} \mathrm{C}$ to $15^{\circ} \mathrm{C}$ tends to lower the growth of some of the isolated fungi (Alternaria alternata, Aspergillus parasiticus and Thielavia terricola). This tallies with the findings of Bristoneet al. (2011).In corroboration with this study, Gulzar et al. (2011) found that the best temperature range for maximum growth of three fungi (Pyricularia grisea, Helminthosporium oryzae and Rhizoctonia solani) of paddy seedlings in the valley of Kashmir in India fell between $5^{\circ} \mathrm{C}$ and $35^{\circ} \mathrm{C}$. This shows generally that the fungal flora virulence to infect rice seedlings irrespective of their taxonomic class is temperature dependent and the range is between $5^{\circ} \mathrm{C}$ to $40^{\circ} \mathrm{C}$.

This present study has shown that rice seedling diseases caused by the three (3) species of isolated fungi are favored within the relative humidity range of $32.5 \%$ to $59.5 \%$ and $100 \%$ for some of the isolates (Alternaria alternata, Aspergillus parasiticus,) while Thielavia terricola showed no radial growth at $80 \%$ relative humidity and $100 \%$ relative humidity. This indicated that humid atmosphere favors the growth and development of the organisms hence, the prevalence of the diseases as supported by Channya (1991) who showed that presence of moisture (relative humidity) predisposed plant tissues to microbial infections. However, the failure of Thielavia terricola to grow under higher relative humidity may not be unconnected with the fact that relative humidity value of $80 \%$ and above entails rainfall meaning that only fungal flora that has inherent hydrophilic character can thrive under such high moisture condition. Reis et al. (2006) reported that the number of conidia produced was low at $74 \%$ relative humidity and greater at $80 \%$ relative humidity, but declined slightly at $100 \%$ relative humidity, this agrees with the findings of this study whereby after progressive increased in radial growth of the isolated fungi over relative humidity regimes of $32.5-80 \%$, it declined at $91 \%$ and $100 \%$ relative humidity. This is to indicate that higher relative humidity entails rainfall under which only aquatic fungi and hydrophilic fungal flora can survive.

\section{CONCLUSION}

This study has shown that Alternaria alternata, Aspergillus parasiticus, andThielavia terricola were responsible for the rice seedling diseases at Dadin Kowa Irrigation Scheme and that environmental 
Bajopas Volume 10 Number 1 June, 2017

factors such as temperature and relative humidity

It is apparent from the study that low temperature and low relative humidity do not support the growth of Alternaria alternata, Aspergillusparasiticus, and Thielaviaterricola Therefore, it is highly recommended that rice seedlings prior to transplanting should be stored at low temperature

\section{REFERENCES}

Alexopoulus, C.I. and Mims, C.W. (1986).An Introductory Mycology. London, Macmillan Press Pp. 340.

Bristone, B., Chimbekujwo, I.B. and Pukuma M. S. (2011).Control of Post-Harvest Fungal Rot of Potatoes Ipomoea batatas (Linn) inYola, Adamawa State, Nigeria.Nigerian Journal of Botany24(1): 43 - 51

Channya, F.K. (1991). Fungi Associated with PostHarvest Rot of Plantains (Musa paradisiaca L.) in South Western Nigeria. Master's Dissertation Department of Botany/Microbiology, University of Ibadan, Ibadan. Nigeria

Chimbekujwo, I.B. (1994).Two Post-Harvest Fungal infections of Carica papaya L. Fruits in Ibadan. Journal of Technology and Development.4:21 - 29.

Ekeleme, F., Kamara, A.Y., Omuigui, L.O., Tegberu, A., Mshelia, J. and Onyibe, J.E. (2008). "Guide to Rice Production in Borno State, Nigeria. Http://Www.iita.Org.

Frazier, W.C. (1978).Food Microbiology.U.S.A Tata McGraw Hill.Co. 78 Pp.

Gulzar A., Garg V.K., Pandit A.K., Anwar A. and Salim A. (2011). Disease Incidence of Paddy Seedlings in Relation to Environmental Factors under Temperate Agro climatic Conditions of Kashmir Valley. Journal of Research and Development 11. have effects on the development of the diseases;

and low relative humidity to avoid infection due to this isolated fungi and this may contribute significantly in controlling the heavy losses our indigenous farmers incurred because of this fungi both at harvest and post-harvest level

Kim, V. K., and Xiao, C. L. (2005). Influence of culture media and environmental factors on mycelial growth and picnidial production of Sphaeropsis Mycologia,97(1): 25-32.

Malik, V. K., and Singh, S. (2004). Effect of temperature and relative humidity on teliospore germination in Ustilagohordei. $\mathrm{J}$. Mycol. Plant Pathol.34: 410-411.

Reis P.R., Lakhpale,N., Kotasthane, A.S. and Thrimurthy, V. S. (2006). Effect of Lesion Age, Humidity and Fungicide Application on Sporulation of Causative Agent of Brown Spot of Citrus. Indian Journal of Phytopatology32: $320-329$

Sharma, R. and Razak, R.C (2003).Keratinophilic fungi: Natural Keratin Degrading Machines; Their solation, Identification and Ecological role. Resonance, 28-30.

Snowdon, A.C. (1990). A Colour Atlas of Post-Harvest Diseases and Disorders of Fruits and Vegetables. Cambridge University Press Pp 128-140.

Thomas, G.A. (1979). Medical Microbiology Macmillan Publishers London Pp403. 